\title{
The Relationship between English Teacher's Praise and English Learning Achievement of The Tenth Grade of SMK Negeri 9 Samarinda
}

\author{
Dzul Rachman ${ }^{1}$, Dedi Rahman Nur ${ }^{2}$ \\ Fakultas Keguruan dan Ilmu Pendidikan, \\ ${ }^{1}$ Mulawarman University, ${ }^{2}$ Universitas Widya Gama Mahakam Samarinda \\ email: 1dzulrachman@gmail.com, 22d.blues84@gmail.com
}

\begin{abstract}
Reinforcement is one of the strategies in classroom management, which is familiar among teachers. One of the types of reinforcement in social reinforcement is praise. Praise can function as a tool for instruction and for increasing social and academic behaviors. To be effective, the student must view the attention provided through praise as pleasurable or motivational. The design of this study was correlation design. The research participant was the tenth grade students of SMK Negeri 9 Samarinda. The purposes of this study are to find out how is relationship between the teacher's praise and the English learning achievement tenth grade of SMK Negeri 9 Samarinda and is there any significant relationship betweenEnglish teacher's praise and English learning achievement. The researcher conducted observation for a month, distributed questionnaires and collected the result of achievement test from the teacher, as the instruments of this study. Then the collected data were analyzed in order to find out the manifestation of reinforcement applied by the teacher. After analyzing the data gained through the observation, the researcher found out that English teacher praise significantly correlate with the English learning achievement of tenth grade SMK Negeri 9 Samarinda $(r-$ value: $0,442>$-table: 0,334$)$. From the questionnaire, it was found that the students showed positive response or opinion toward the implementation of reinforcement in their class for example teacher praises immediately, frequently, enthusiastically, by using eye contact, uses many kinds of word praise and explains the reason why he praises students.
\end{abstract}

Keywords: Reinforcement, Social reinforcement, Praise, English learning achievement, Classroom management

\section{INTRODUCTION}

As a teacher to be, the researcher knows that teaching and learning process involves the teachers and the students as main part of teaching and learning activities. Teacher can suggest many techniques, which deal with classroom activities to provide an advance organizer for teaching students systematically. In order to achieve the learning goals, those techniques become one factor, which need to be considered in order to gain or maintain students' cooperation.

One of the greatest frustrations mentioned by many teachers for many years is that their students are often not motivated to learn. Teachers quickly come to recognize the warning signs of poor motivation in their 
classroom: students put little effort into homework and class work assignments, slump in their seats and fail to participate in class discussion, or even become confrontational toward the teacher when asked about an assignment.

So in the classroom, when teacher conducts the teaching and learning, she/he deals with students to replace uncooperative behavior to cooperative behavior. But the reality is that teacher in his/her class finds differences among students' behavior. Some of them probably cooperate with the process of teaching and learning, while the others show disruptive behavior which might interrupt the process of teaching and learning.

The same frustrations also annoyed the researcher at the early days of conducting teaching practicum as the part of Mulawarman University's academic requirement. The researcher was placed at SMK Negeri 9 Samarinda to run the teaching practicum. The researcher did an observation of the classes where the researcher would teach before starting to handle it by the researcher's own. Some warnings about the students of the class came from the school principal and teachers, which judged that the researcher was so "lucky" to have the most disruptive and unmotivated class ever.

The condition stated above burdened and frightened the researcher at that time and therefore had challenged the researcher to discover how disruptive, unmotivated, uncooperative, unable, and unwilling those students were. So the researcher whose one of her responsibilities as a teacher to be is keeping the student on-task and engage in learning activities. The researcher tries to seek an appropriate strategy in managing classroom to accomplish important learning goal. And one of the strategies, which is familiar with the teachers, is reinforcement. Reinforcement from the teacher such as praise, reward, point, certificate or toys has the relationship with the result of achievement of students.

Based on the problems stated above, the aims of this study were: to know how is relationship of the teacher's praise and English learning achievement the tenth grade students of SMK Negeri 9 Samarinda; to find out the significant relationship of English teacher's praise and students' English learning achievement. To be explicit, the scope of this study is limited into the following: as one form of Reinforcements this study was focused on Praise. The instrument was used on EFFECTIVE PRAISE as teacher's reinforcement of tenth grade of SMK Negeri 9 Samarinda; the researcher limits this study only to analyze PRAISE which is given Immediately, Frequently, Enthusiastically, Using Eye Contact, Describe Behavior and Variety of praise; the study did in SMK Negeri 9 Samarinda, with the X-Pembibitan students as thepopulation and sample.

\section{Definition of Reinforcement}

(Heffner, 2001) mentions about definition of Reinforcement; that the first study of how the process of learning affects our 
behavior was argued by John. B. Watson. He defines learning as the process leading to relatively permanent behavioral change or potential behavior change.

According to (Atherton, 2003), the theory proposes by B. F. Skinner emphasizes the changes in behavior as the results of an individual's response to events (stimuli) that occur in the environment. And this stimulus response theory is the key element of reinforcement.

The psychologists state that reinforcement refers to anything stimulus, which strengthens or increases the probability of a specific response (Heffner, 2001). In another word, reinforcement deals with behaviors, which need to be strengthen where the results will show an increase of occurs in the frequency of desired behavior.

Reinforcement is divided into two types, namely positive reinforcement and negative reinforcement. (Zanden, 1984) shares psychologist definition to the terms of positive and negative reinforcer: "A stimulus whose 'presenttation' leads to increase in strength of a response is said as positive reinforcer (for example: adding praise will increase the chances of a child cleaning his/her room). And one in which the 'removal' of the stimulus leads to an increase in strength of a response is a negative reinforcer (imagine your sister hits your face every morning to wake you up six, and you finally cam wake up before six, then the 'hit' stops)."
Relating to the definitions given, there is wrong assumption that appears in teacher and students' mind. They regard the negative reinforcer is similar with punishment. Meanwhile, what is meant by punishment is totally different with negative reinforcement.

\section{Process of Reinforcement}

In the classroom setting, teacher takes charge of his own classroom and applies in the reinforcement so that the students maintain the desired behaviors in order to engage in learning activities. (Atherton, 2003) mentions three principles need to be considered to apply the reinforcement technique, those are;

a. Behavior that is positively reinforced will reoccur; intermittent reinforcement is particularly effective.

b. Information should be presented in small amounts so that responses can be reinforced (shaping).

c. Reinforcement will generalize across similar stimuli (stimulus generalization) producing secondary conditioning.

\section{Concept Of Praise}

Positive reinforcement should follow immediately after good behavior. It should be specific and initially continuous, slowly moving on an intermittent schedule. Material reinforcers provide the child with something tangible. Social reinforcers are move versatile, and, even if material reinforcers are used, a kind word from the teacher should always accompany them. 
According to (Hitz, 1989)research on the use of teacher praise in the classroom, effective praise was thought to occur when the teacher positively acknowledged students' work. Furthermore, (Thomas, 1991) referred to praise as positive reinforcement, with consistent praise thought to encourage desirable behavior, while extinguishing undesirable behavior.

Many teachers attempt to use praise as a form of positive reinforcement in order to motivate students to achieve and behave in positive ways. However, as (Brophy, 1988) points out, trying to use praise as a systematic reinforce in a classroom setting is impractical. Even if teachers were able to praise frequently and systematically, say once every 5 minutes, the average student would still be praised less than once every 2 hours.

Otherwise, simply remind the student what behavior you are looking for. Then when the student performs the desired behavior, use praise and other forms of reinforcement. Specific praise includes verbal or written statements to a student that recognize a desired or correct behavior. Praise can function as a tool for instruction and for increasing social and academic behaviors. To be effective, the student must view the attention provided through praise as pleasurable or motivational, as according to Brophy (1998) "Praise can be used to build positive relationships with students and assist in creating a supportive classroom environment".

Praise is most effective when it is: Immediately delivered, given frequently, given enthusiastically, the teacher look at the child, the teacher describes the behavior, and a variety of praise statements are used. (Loveless, 1996)

\section{The relationship of Teacher's reinforcement and class participation}

Teacher's reinforcement for students is namely to foster self-esteem, autonomy, selfreliance, achievement, and motivation for learning. Most teachers praise students in order to enhance progress toward these goals. Some praise statement may have the potential to increase confidence in themselves. In a study of second graders in science classroom, (Rowe, 1974) found that "praise increased students' confidence in their answers and improve number of verbal responses they offered". The students exhibited many characteristics indicative of high self, such as responding in clear tones and showing much of persistence or desire to keep trying. In addition, students frequently have a confidence to do interaction with teachers.

In a series of six studies of subjects ranging in age from third grade to adult, (Meyer, 1979) found that under some conditions, praise led recipients to have high expectations of success at difficult tasks, which in turn increase the persistence and performance intensity at the task. It seems that certain kinds of praise may set up even the less capable students for success.

\section{The relationship of teacher's reinforcement and assignment completion}

Many teachers have used token or another program as a kind of reinforcement for increasing motivation of students in assignment completion. When a teacher promises an award if the student will complete an assignment or when a teacher promises a prize acknowledge a 
successful performance, she or he introduces reinforcement into learning environment. Teacher's reinforcement such as token or reward procedures significantly increased assignment completion. An experimental study illustrated that high rates of academic completion could be generated and maintained, and that when points and fines were no longer contigent, completion responding decreased. The reapplication of token contigencies increased completion again. (Burnett., 2002)

\section{The relationship of teacher's reinforcement and student's attitude}

The best behavior management is good instruction. Teacher's good instruction, and a good instruction fit are reinforcing students who are engaged in the lesson, so they are motivated to learn and they feel good about their involvement and success with the tasks.

Additionally, students who are engaged in the lesson are not focusing their energy on misbehaving. Building in reinforcement strategies to address specific behaviors or to mortivate students can be a simple and effective way to re-energize class.

\section{The relationship of teacher reinforcement and student's behavior}

Many positive educational outcomes can be framed in terms of desirable behavior. Teacher consider behaviors such as attending school regularly and promptly, being actively engaged during classroom lessons, showing respect for others, making good grades, and graduating from school as desirable ways to 58 behave. Because educators value these ways of behaving and because they would like to see students engage in these ways of behaving more frequently, they find merit in classroom management practices, the most popular and the most effective of which involves the strategic use of positive reinforcers, negative reinforcers, and extrinsic rewards (Atherton, 2003)

\section{METHOD}

This study is intended to find out whether the implementation of praise significantly correlate to English learning achievement X-Pembibitan students of SMK Negeri 9 Samarinda, as well as the response and opinion of the students about the implementation of praise in their class. The main design of this study was quantitative correlation. In this study, the variables were English teacher's praise and English learning achievement. The population of this study was the students of X-Pembibitan of SMK Negeri 9 Samarinda. The instruments to collect data were achievement test and questionnaire. The data of the study were on the students' score and result of questionnaire. The students' score are related to their result on questionnaire. To know the relationship of both research variables, the data was analyzed using Product Moment Correlation formula.

\section{FINDINGS AND DISCUSSION}

In pre-research on 17December until 24

December 2013 for about 2 meetings, the researcher knew that students were unable and 
unwilling to follow the lesson. Furthermore, they were disrespectful to the teacher, being such an annoyance to their friends, inattentive toward the lesson. They were also often disobeyed the school or class regulation. The teacher regularly assigned the students with various tasks which should be submitted. Previously, there were only few students to submit the assignments. The number of students who submitted the assignment changed in each meeting, depended on the level of difficulty of the assignment. The students tended to do easy tasks only, and left the difficult ones. They also liked to cheat on their friends' work so that they could submit their assignments easily.

The students were quite disruptive in the class. They came in and out of the class, walked here and there inside the class, talking out loud to their friends, etc, as they wish. They were obviously disrespectful toward their teachers and school regulations. They were also disrespectful to their friends who tried to get involved during the lessons. The students showed low attitudes during pre-research period. They were unwilling to receive feedback from the teacher regarding the lessons being taught, they were unwilling to cooperate well with their friends, and they showed no respect toward their friends' opinion or effort regarding the lesson.

In observation, the researcher used observation guide with checklist technique to measure English teacher's praise. There were 6 indicators to measure such as praises immediately, frequently, enthusiastically, eye contact, variety of praise and describe behavior. There were 1 indicator that always arises in observation period such as teacher used variety of words praise when they did the task well, answered the questions, got good score and when they behavewell.

In observation period, the researcher found the students changed in class participation, Assignments Completion, Student's Behavior and Student's Attitude. The students competed each other to participate in every activities held by the teacher as they wanted to get praise as many as possible. The situation of the class often got crowded as the students tried to attract the teacher to pick them up to do something, such as answering questions, reading passages, translating words or sentences, etc.

(Meeting 1):

The teacher reinforced the student immediately after answer the question by saying "that's right you can answer my question well" or "you are good"for those who could answer correctly 
and saw the students who gave praise after that

he smiled.

(Meeting 2):

I noticed that he gave comment to their work immediately such as "fantastic you do the assignment well”, “ok, very good you can do it” and saw the students (group) who gave praise.

For example the teacher used praise frequently:

(Meeting 3):

After making sure all of his students made it. $\mathrm{He}$ walked around again, and helped students to find out difficult words using dictionary. The teacher praised several groups of the student because answered the assignment well.

(Meeting 4):

Several students raised their hand up to answer the question. The teacher praised the student by saying "wonderfull, super, good work and very good" for those who could answer correctly.

For example the teacher describe behavior when give praise:

(Meeting 1):

The teacher reinforced the student immediately after answer the question by saying “that's right you can answer my question well" or "you are good" for those who could answer correctly and saw the students who gave praise after that he smiled.

For example the teacher used praise enthusiastically:
(Meeting 3):

I noticed that he gave comment to their works such as “You're on the right track”, “Кеep up the good work" and he smiled.

(Meeting 4):

“That's nice!" he smiled when a student showed his picture to him, "Ok, who hasn't finished, raise your hand!" many of them, raise their hands up.

For example the teacher used variety of praise:

(Meeting 1):

The teacher reinforced the student immediately after answer the question by saying "that's right you can answer my question well” or "you are good" for those who could answer correctly and saw the students who gave praise after that he smiled.

(Meeting 3):

"You're on the right track", “Keep up the good work" and he smiled.

(Meeting 4):

He said immediately"good job, excellent, amazing and super" for who get score above 70.

In assignment completion, most of the students regularly submitted their assignment, finished them by their own, and had quite improvement in their works. In the same period, there were quite improvement in behavior and attitude. Most of the students behaved 
themselves, they showed positive behaviors. Even if they did not, they would reconsider what they had done because their teacher did not praise them.

All the facts that the researcher found on the field during the observation regarding the students' achievement matched the result of $r$ tests. The researcher could obviously see that there were dramatic positive changes of the students' class participation, assignment completions, behavior and attitude. This assumption of researcher's is eventually supported and proved by the statistical processing of the r-test. Furthermore, the questionnaire results also showed the positive opinion of the students toward the implementation of English teacher praise. The students' answers of the questionnaire were also supported by real situation that the researcher saw during theobservation.

\section{CONCLUSION}

The teacher applied praise (good, good job, excellent, good work, very good and super) as positive reinforcement during English lesson. Praise itself is the center of reinforcement supported by generalized reinforcement and token reinforcement. In addition, there is a significance correlation between English teacher's praise and students' English learning achievement of the tenth grade students of SMK Negeri 9 Samarinda. It has been proved that the comparison between r-value and r-table at $\mathrm{N}=$ 35 and $\mathrm{p}=0.05$ used in this study indicated that r-value was higher than r-table $(1,00>0,334)$.

\section{REFERENCES}

Atherton, J. S. (2003). Learning and Teaching; Behavior Modification. Retrieved from www.dmu.ac.uk/ jamesa/learning/behavi or_mod.htm

Brophy, J. E. (1988). Teacher Praise: A Functional Analysis. Review of Educational Research.

Burnett., P. C. (2002). Teacher praise and feedback and students' perceptions of the classroom environment., 22, $n$ (Educational psychology,).

Heffner, C. L. (2001). Introduction to Learning Theory and Behavioral Psychology.

Hitz, R. and A. D. (1989). Praise in the Classroom. ERIC Clearinghouse on Elementary and Early Chilhood Education Urbana IL.

Loveless, T. (1996). Teacher praise, in $H$ Reavis, S.Kukic, W. Jenson, D.Morgan, D.Andrews, \& S. Fister (Eds.), Best Practices: Behavioral and Educational Strategies for Teachers.

Meyer, W. (1979). Informational Value of Evaluative Behavior: Influences of Social Reinforcement on Achievement. Journal of Educational Psychology.

Rowe, M. B. (1974). Relation of Wait-Time and Rewards to the Development of Language, Logic and Fate Control: Part II--Rewards. Journal of Research In Science Teaching. 
Thomas, J. (1991). You're the greatest! A few well-chosen words can work wonders in positive behavior reinforcement.

Zanden, J. W. . (1984). Social Psychology (3rd edition). New York: Random House, Inc.,. 